\title{
ARTICLES
}

\section{PRELUDE TO THE SEPARATION OF POWERS}

\author{
N.W. BARBER*
}

THIS article is an exploration of the concept of the separation of powers. It does not seek to advance a fully formulated account of the doctrine; rather, it seeks to show what the many different interpretations of the concept have in common, and defend the validity of a diversity of conceptions. The essence, though not the whole, of separation of powers lies in the meeting of form and function; the matching of tasks to those bodies best suited to execute them. The core of the doctrine is not liberty, as many writers have assumed, but efficiency. This article will attempt to show the considerations generated by the separation of powers when the concept is animated by a thin political theory, that is, principles which are so uncontroversial virtually all political theorists would endorse them. Relying on these thin normative assumptions, the article will examine how far it is possible to claim that the structures of the courts and the legislature have implications for the tasks that ought to be assigned to them; how far a link can be drawn between the institutions of the legislature and judiciary, and the legislative and judicial function. Though the considerations identified are of weak force, their strength is such that they will continue to apply once a thicker normative theory is introduced. By adopting thin normative assumptions we are able to identify the structural concerns that are at the core of the concept, even if they are too shallow to allow us to build a complete model of the separation of powers. ${ }^{1}$

* Brasenose College, Oxford. This article follows on from N.W. Barber, "Sovereignty Reexamined: Courts, Parliament and Statutes" [2000] O.J.L.S. 130. Thanks are due to Adrian Blau, Brad Miller, Bronwen Morgan and Dale Smith, who commented on earlier drafts.

1 This enterprise should be contrasted with work undertaken by theorists such as Bruce Ackerman, who has attempted to construct a complete vision of the separation of powers; see B. Ackerman, "The New Separation of Powers" (2000) 113 Harv.L.Rev. 633. The present article does not pose a direct challenge to Ackerman's work. 


\section{The Ambitions of Separation of Powers}

The doctrine of separation of powers has come to play a significant part in recent constitutional debate in the United Kingdom. This renaissance is largely due to the work of Eric Barendt, who has argued that the doctrine has a fundamental role to play in the British constitution. ${ }^{2}$ Barendt, following Vile, ${ }^{3}$ distinguishes between "pure" and "partial" versions of the doctrine. The pure theory calls for complete separation of the three branches of the state; a strict delineation of functions between the executive, the legislature and the judiciary. The division of power acts as a restraint on the power of the state. ${ }^{4}$ An alternative vision of the doctrine, the "partial" version, instead emphasises the significance of checks and balances within the constitution. Each of the institutions of state is given some power over the others, their functions are deliberately constructed so that they overlap. Friction is consequently created between the branches of state; no one institution has absolute autonomy. Both of these versions of the doctrine make two critical assumptions. First, that it is possible to identify and group certain powers as "legislative", "executive" or "judicial".5 Judicial power is the application of the general law to particular cases. Legislative power is the power to enact law and to hold the executive to account. Executive power is the power to administer the law, and the power to undertake foreign affairs. Secondly, that there is a natural connection between these powers and the corresponding state institution. Barendt rejects the pure theory; some overlap of functions and office-holders is welcomed. The institutions are each given powers that the pure theory would have denied them in order to enable them to limit the conduct of the other institutions. ${ }^{6}$ Constitutions that attempt to follow the pure version of the doctrine quickly discover its impracticalities: one institution, normally the legislature, quickly gains ascendancy over the other two. With no powers to wield against the aggressor the two weaker branches of state are left at the mercy of the third. ${ }^{7}$

${ }^{2}$ E. Barendt, "Separation of Powers and Constitutional Government" [1995] P.L. 599; E. Barendt, An Introduction to Constitutional Law (Oxford 1998), at pp. 14-17.

${ }^{3}$ M. Vile, Constitutionalism and the Separation of Powers, 2nd ed. (Indianapolis 1998), ch. 1; W.B. Gwyn, The Meaning of the Separation of Powers, Tulane Studies in Political Science, Vol. 9 (Tulane 1965), ch. 1.

${ }^{4}$ Vile, Constitutionalism, at p. 14.

${ }^{5}$ Barendt does not investigate the nature of these types of power at any length. On Montesquieu's definition of these powers see generally Vile, Constitutionalism, ch. 4, and Montesquieu, The Spirit of the Laws, transl. by A. Cohler, B. Miller and H. Stone (Cambridge 1989), Bk. 11, ch. 6. Morgan explores the division as reflected in case law in D. Morgan, Separation of Powers in the Irish Constitution (Dublin 1997).

${ }^{6}$ Vile, Constitutionalism, at pp. 19-20.

${ }^{7}$ Ibid., at ch. 6, esp. pp. 161-162; J. Madison, in J. Madison, A. Hamilton and J. Jay, The Federalist Papers, ed. I. Kramnick (London 1987), No. 46. 
Barendt argues that the purpose of separation of powers is to protect the liberty of the individual. It does this by making state action more difficult. This view of the doctrine gains the support of Justice Brandeis who, in Myers v. U.S., wrote that the purpose of separation of powers "was not to avoid friction, but, by means of the inevitable friction incident to the distribution of the governmental powers among three departments, to save the people from autocracy." 8 Concerted state action is therefore made more difficult by the existence of checks and balances between the various organs of state. With this aim in mind Barendt is able to tackle some of the challenges posed by opponents of the doctrine. The classic, and the most obvious, objection is that there is no natural division of power between the three institutions of the state. The strong version of the objection argues that there is no material distinction between legislative, judicial and executive powers. ${ }^{9}$ The weaker version of the objection contends that the division is blurred, ${ }^{10}$ and, more subtly, that even so far as the division can be maintained this does not provide a reason to match these powers to the corresponding state institutions. ${ }^{11}$ Barendt's response is brisk. The purpose of the doctrine, according to Barendt, is not, primarily, to identify the best, or natural, holder of a particular power. The doctrine rather aims to protect liberty through division of power. The precise delineation of this division is not of great significance; all that separation of powers requires is that some division of power be decided upon and adhered to. Barendt uses various cases to show that British judges can draw the lines required by the doctrine in a largely principled fashion, ${ }^{12}$ but where no principled line can be drawn, or the division is controversial, the first concern of the doctrine is that an allocation is made. So, Barendt can avoid the charges of the critics of the doctrine by arguing that the allocation of functions to institutions is merely a means to an end; it does not matter whether powers are always allocated to the most appropriate institution. ${ }^{13} \mathrm{~A}$ rough, perhaps intuitive, division will suffice.

Barendt's contentions are elegant and persuasive, but must ultimately be rejected. They are too ambitious. Barendt has equated

${ }^{8}$ Myers v. U.S. (1926) 272 U.S. 52, at p. 293; see also Montesquieu, Spirit of the Laws, Bk. 19 ch. 27, and S. Calabresi and K. Rhodes, "The Structural Constitution: Unitary Executive, Plural Judiciary" (1992) 105 Harv.L.Rev. 1153, at p. 1156, where separation of powers is described as "institutionalising conflict".

9 I. Jennings, Law and the Constitution, 5th ed. (London 1959), at pp. 281-282, and 303.

${ }^{10}$ A point recognised by Madison, Federalist Papers, No. 37, at p. 244.

${ }^{11}$ G. Marshall, Constitutional Theory (Oxford 1971), at pp. 99-100.

12 Barendt (1995) P.L. 599, at p. 605, citing Commissioners of Customs and Excise Ltd. v. Cure and Deeley Ltd. [1962] 1 Q.B. 340 and Liyanage v. The Queen [1967] 1 A.C. 259.

13 Barendt [1995] P.L. 599, at p. 606. 
the doctrine of separation of powers with a theory of the state. At least two unargued normative theses underpin Barendt's article. First, that liberty and a strong state are inevitably opposed to each other, that the citizen can only be truly free within a state whose power for concerted action is limited by institutional conflict. Secondly, that it is the task of the judges to protect the liberty of the citizen from the other organs of the state by ensuring that this division exists. These contentions may both be correct, ${ }^{14}$ but Barendt, by casting his article in terms of the doctrine of separation of powers, has avoided the difficult issues that they raise. If Barendt's doctrine was adopted by the courts this would necessitate a radical shift in the balance of power between the courts, Parliament, and the executive. It would require, or at least encourage, the courts to challenge the legal supremacy of Parliament. ${ }^{15}$ Hard questions about the nature of democracy and the claims of individual rights are raised, but left unaddressed. Separation of powers has become a political platform without the support of political argument. Barendt is able to avoid directly engaging in political debate by concealing these issues behind an ostensible theory of a constitution. ${ }^{16}$

Separation of powers claims to be an exercise in constitutional theory, and in doing so distinguishes itself from exercises in pure political theory. Whereas political theory seeks to set out the goals that collective action ${ }^{17}$ should pursue, constitutional theory is concerned with the practical ordering of power-wielding institutions and the structures of the relationship of the individual with these institutions. ${ }^{18}$ Crudely, political philosophy is about ends, and constitutional theory is about the means. The precise divide between these two activities is blurred but remains of enormous significance. Whilst it is possible, though perhaps unwise, for a political philosopher to ignore constitutional theory, it is impossible for a constitutional theorist to ignore political philosophy. A political philosopher can produce a utopian vision of the ideal world; uncluttered by the limitations inherent in all human

\footnotetext{
${ }^{14}$ Ironically Montesquieu, whom Barendt frequently relies on for support, saw the courts as one of the most dangerous branches of state: Montesquieu, note 5 above.

${ }_{15}$ Barendt (1995) P.L. 599, at p. 616, and Barendt, Introduction, at p. 17.

${ }^{16}$ See further A. Tomkins, "Of Constitutional Spectres. Review of Eric Barendt: An Introduction to Constitutional Law" [1999] P.L. 525 and P. Manent, An Intellectual History of Liberalism, transl. R. Balinski (Princeton 1995), who makes a similar criticism of Montesquieu, at pp. 54-55.

${ }^{17}$ I deliberately avoid the term "state". The classical view of the state is as a geographically bounded organism. Modern constitutional writing has shown that constitutions can transcend geography; providing political and legal constraints at an international, national and subnational level. See especially N. MacCormick, "Judicial Pluralism and the Risk of Conflict" in Questioning Sovereignty (Oxford 1999), and the other essays in that volume.

18 D. Morgan, Separation of Powers, at p. 282.
} 
endeavour. ${ }^{19}$ A utopian constitutional theory, on the other hand, would be a waste of time. Writings about constitutions are always undertaken in the service of political theory. Whilst it is possible for a writer to produce a purely descriptive account of the functioning of constitutions, the usefulness of this descriptive work will lie in its contribution to those who are seeking to change or justify existing constitutional orders. Any normative claims made by a constitutional writer must draw on political theory; there are no value-neutral assessments that can be made of constitutions, or, indeed, any other social practice. Constitutional writing and political theory are closely intertwined disciplines; it is only the practical focus of constitutional study that allows them to be differentiated. Later in this article the interplay of political theory and the separation of powers will be examined in more depth. Separation of powers is a theory of the ordering of collective action; it must be prefaced by a political theory if it is to possess any normative force.

Is it possible to write anything useful about separation of powers abstracted from political theory? The previous paragraphs might indicate that critics of the separation of powers were right; that there is nothing to be gained from pursuing the concept any further. If separation of powers is merely a disguise for political theory, surely it would be better to abandon the disguise and debate directly with the normative contentions that hide behind the concept? Though there is much to be said for this view it is, perhaps, overly pessimistic. There is much to be gained from classical writings on separation of powers. A clue may be found in the persistence of a second possible aim of separation of powers: the claim that the purpose of the doctrine is to promote efficient state action. ${ }^{20}$ Writers on separation of powers have frequently contrasted the claims of efficiency and liberty. These have been treated as rival justifications for the doctrine, bordering on contradiction. John Locke is sometimes read as advocating separation of powers in order to ensure the efficiency of government action. ${ }^{21}$ Vile has strongly attacked this characterisation of Locke's work, and has convincingly demonstrated that Locke was also concerned with the protection accorded to individual liberty by the doctrine. ${ }^{22}$ However, this should not blind us to the

19 N. Komesar, Imperfect Alternatives (Chicago 1994), at pp. 37-38.

${ }^{20}$ Gwyn, Separation of Powers, at pp. 32-34.

21 Barendt (1995) P.L. 599, at p. 602; Morgan, Separation of Powers, at p. 4; P. Laslett, in J. Locke, Two Treatises of Government, ed. P. Laslett (Cambridge 1988), at pp. 118-120, provides qualified and indirect support for this view. See also W. Gwyn, "Separation of Powers and Modern Forms of Democratic Government" in R. Goldwin and A. Kaufman (eds.), The Separation of Powers-Does it Still Work? (Washington 1986), at p. 70.

22 Vile, Constitutionalism, at pp. 63-74. 
significant role that efficiency plays in Locke's Second Treatise. Locke was attempting to fashion a vision of civil society that would be so great an improvement on individuals' rights within a state of nature that they would voluntarily surrender these rights in order to participate in the common good. ${ }^{23} \mathrm{He}$ crafted a constitution that took account of human frailty. Limits were placed on institutions to protect against abuse: the legislature, for example, was empowered to create laws, but denied the power to adjudicate in particular cases. This restriction was required because there was a risk that the legislators would not be able to distinguish between their law-applying and law-making functions, ${ }^{24}$ or would not show sufficient care when deciding issues that did not directly concern them. ${ }^{25}$ Locke believed it was a prerequisite of legitimacy that the constitution did not retard citizens' interests, but he also believed that the constitution must be sufficiently effective to provide positive protection for citizens. Consequently, the legislature ought not to pass judgment on particular cases because it was structurally ill equipped to undertake this task; even if it acted in good faith it was unlikely to adjudicate as fairly or as impartially as a court. According to Locke, it was not sufficient that the state avoided enacting laws that ran contrary to the public good, it must also enact laws that promoted the public interest. Thus, efficiency and liberty are combined; an efficient constitution is one that protects and fosters liberty. Having determined, rightly or wrongly, that the central purpose of civic society was the protection of property, Locke created a constitution that would secure this goal. The specific tasks that needed to be performed were allocated to the state institution that could most efficiently execute them. Locke was advocating a form of separation of powers not in order to slow down the running of the state but in order to ensure that it ran well. Powers were divided in order to facilitate the purposes for which the state existed.

A similar analysis can be undertaken of the role of the doctrine in the origins of the United States constitution. A reading of the debates of the Federal Convention simply does not support Brandeis' view $^{26}$ that the purpose of separation of powers was to slow down government. ${ }^{27}$ Madison $^{28}$ recognised the need for a division of powers in order to protect the people from tyrannical

${ }^{23}$ Locke, Two Treatises, para. 1-123.

${ }^{24}$ Ibid., para. 137.

${ }^{25}$ Ibid., para. 125.

${ }^{26}$ Note 14 above.

${ }^{27}$ A. Anderson "A 1787 Perspective on the Separation of Powers", in R. Goldwin and A. Kaufman (eds.), The Separation of Powers-Does it Still Work? (Washington 1986), at p. 145.

${ }^{28}$ Madison, The Federalist Papers, esp. No. 47. 
government; but it should not be assumed that the separation of powers was treated merely as a brake on power. Though the doctrine made it harder for an oppressive regime to rule, it also aimed to enhance good government. ${ }^{29}$ A central function of the state was seen to be the promotion of liberty, and the constitution was therefore drafted in a manner that would facilitate this purpose. One delegate at the Convention criticised the concentration of power in the Continental Congress: when all the powers of state were vested in a single body "none of them can be used with advantage or effect." ${ }^{30}$ Liberty was imperilled by the inability of the omnipotent body to create, enforce and adjudicate upon laws to protect the citizen. The efficient allocation of functions to institutions was the allocation that best served to protect, and to promote, liberty.

The discussion of Locke and the founders of the American Constitution demonstrates the interplay between liberty and efficiency in the working of the separation of powers. Liberty is identified by Locke and the Founders as the justification for collective action, though they have very different understandings of what liberty entails. Both then go on to develop models of constitutions that aim to promote these purposes. A constitution is efficient in so far as it promotes the purposes for which it was crafted. It is inefficient in as far as it fails to fulfil these aspirations. The notion of efficiency gives the concept of separation of powers some freedom from political theory, but is still, unavoidably, dependent on thin political assumptions. It is possible, though implausible, to imagine a political theorist who rejected efficiency, who believed that powers ought to be allocated at random. Such a theorist would reject the separation of powers as a guide to the crafting of constitutions. However, most of us accept the very weak political underpinning of efficiency: that powers should be allocated to those institutions who are best able to make use of them. Separation of powers instructs drafters of constitutions to attribute the correct function to the correct institution in order to serve better the purposes for which collective action is undertaken. Regardless of the specific political theory that underpins collective action, it is efficiency, not liberty, which is at the heart of separation of powers. The notion of efficiency by itself, however, is not enough to create a version of the separation of powers; it remains a desiccated concept that waits for the introduction of a

${ }^{29}$ Ibid., No. 37, at p. 243. Madison wrote: "Energy in government is essential to that security against external and internal danger and to that prompt and salutary execution of the laws which enter into the very definition of good government."

${ }^{30}$ M. Farrand, The Records of the Federal Convention of 1787, vol. III (Yale 1966), at p. 108; cited in Anderson, note 27 above, at p. 145. 
stronger normative thesis before it generates a full conception of the doctrine that can provide any institutional considerations.

Before moving on to consider the qualifications that must be placed on any abstract discussion of separation of powers it may be well to dispel some possible misconceptions about the notion of efficiency. ${ }^{31}$ The term does not imply that the constitution should be wealth-maximising, or based on an utilitarian moral philosophy. "Efficiency" is used in its non-technical sense of efficacy; an institution is efficient, or efficacious, in as far as it secures the goals set for it to achieve. If, for example, it is the sole goal of the police to catch criminals their efficiency depends on how many criminals they arrest. If, as is more common, the goals are more complex, efficiency depends on how close the institution approaches the optimal balancing of these goals. The police may not simply be judged on how many criminals are caught; they may also be judged on the degree to which people's rights are respected during the investigation, the impact they make on the fear of crime, and the speed with which they identify criminals. Testing the efficiency of an institution requires the clear identification of its goals and a careful practical examination of its outcomes.

\section{The Limitations of the Separation of Powers}

There are two significant limitations on the useful discussion of separation of powers as an abstract constitutional doctrine. First, the mastery of political theory over constitutions makes it difficult to discuss separation of powers in the abstract; the claims of separation of powers will depend upon the particular political theory that drives it. Secondly, constitutional drafting is necessarily a practical exercise. Even if we were able to decide upon a single, coherent, political philosophy the implementation of that philosophy in a specific area would depend to a large extent on the geographical and social make-up of that country.

To over-simplify wildly for the purposes of exposition, there are at least three, inter-connected, levels at which political theory feeds into separation of powers. First, political theory identifies the aims of collective action. Should society maximise happiness, protect citizens' rights or provide an environment in which the brilliant can excel? Secondly, political theory addresses the question of who ought to pursue these aims. What conception of democracy should we adopt? How far, if at all, should individual rights be permitted to over-ride the common will? Thirdly, political theory tackles the question of what ought to be done about disagreement over the

\footnotetext{
${ }^{31}$ Ackerman (2000) 113 Harv.L.Rev. 633, at p. 639.
} 
first two questions. Should we pursue a single moral vision, or should we try to reach a compromise between different claims? These questions may seem very far removed from the separation of powers, but the answers that we give to them are crucial for the working of the doctrine. Each of them has institutional consequences within a constitution.

Thoughts about the proper aims of collective action influence the type of institution that should exist and the tasks assigned to it. If it were decided that, for example, education is worthless and true fulfilment can only be found in physical labour and religious meditation, we would not wish to see universities or schools established within our society. The courts would look very different: judges would not be skilled in the law but would decide issues on the basis of "fairness". Perhaps they would be chosen by age, or because of their piety. This first group of questions relates to what the constitution ought to try to achieve. The second group of questions, of who ought to pursue these aims, also creates complexities within the constitution. Some political theorists place great weight upon democracy as a method of social ordering. For them, it is of paramount importance that collective action be approved by the people as a group. This shows respect for the dignity of those affected by the decision. Others think that no one ought to be compelled to act by others, placing their faith entirely in the market. This shows respect for the autonomy of the citizen, placing a high value on his negative liberty. Some theorists think that rights should "trump" the collective interest, and should be taken out of the democratic forum entirely. These theories have obvious consequences for the constitution. They concern the amount of power given to collective organisations and the allocation of that power. They concern the boundaries of the power of the legislature and the courts. Should the legislature have unfettered freedom to create law? If not, should it be the courts who provide that fetter? This second group of questions recognises that there may be value in the process by which the constitution seeks to facilitate the good. Finally, what are we to do about the diversity of political theories within a society? Should we impose our answers about the first two questions on others, or should we work for compromise? If one group in our community believes that the only source of legitimate authority is scripture, and another believes that the ballot box is the only proper method for resolving disputes, how are we to decide between them? This third group of questions relates to the authority by which the constitution can be established and amended. A constitution cannot, initially, vest itself with authority. The processes adopted by the constitution to resolve 
disputes, contained within the second group of issues, cannot resolve conflicts over the adoption of the constitution itself.

The complexities of political theory create difficulties for those drafting constitutions. All constitutions are shaped by political theory, even though it will often be hard, probably impossible, to demonstrate a straight causal relationship. The link is blurred by two further considerations. First, drafters of constitutions will often find that political theory is under-determinate: it fails to provide concrete answers to particular questions. Often, political theory does little more than tell us that each of two alternatives is desirable, or undesirable, and fails to resolve the conflict between the two. Two competing institutional orderings may possess differing merits that are impossible to adjudicate between: they may be incommensurable. ${ }^{32}$ Secondly, constitutions tend to reflect a wide array of different political theories. The founders of the constitution may have had different personal philosophies that had to be compromised in the course of the creation of the constitution, or, equally likely, lacked coherent individual political philosophies. Over time constitutions change and adapt to reflect movements in the intellectual environment, leaving constitutional debris behind. Whilst these two considerations should warn us against making rash descriptive pronouncements about the link between political theory and a constitution, they do not absolve us of making a normative link. Any criticism of a constitution, or proposal for reform, must be underpinned by a political justification.

A second limitation on the articulation of separation of powers in the abstract is the dependence of the doctrine on the particular society under consideration. ${ }^{33}$ A constitution is, above all else, a practical document; it cannot be constructed in ignorance of local conditions. Any attempt to construct a utopian constitution is predestined to fail. ${ }^{34}$ The constitutional writings of F.A. Hayek fall prey to this criticism. Hayek slides from the justifiable contention that a utopian political theory may be valuable, ${ }^{35}$ in that it provides an aspirational guide to constitutions, to the false claim that the drafting of a utopian constitution is a useful exercise. ${ }^{36}$ This leads him to claim, amongst other things, that all constitutions should

32 On which see J. Raz, The Morality of Freedom (Oxford 1986), ch. 13, Komesar, Imperfect Alternatives, at p. 34 .

33 Komesar, Imperfect Alternatives, at p. 114.

34 This is graphically illustrated by the constitutional failure of Latin American countries that imported the United States' constitution wholesale. See Ackerman (2000) 113 Harv.L.Rev. 633, at p. 646, and the materials cited therein.

${ }^{35}$ F.A. Hayek, Rules and Order, at p. 65, reprinted in F.A. Hayek, Law, Legislation and Liberty (London 1982).

${ }^{36}$ F.A. Hayek, The Political Order of a Free People, reprinted in F.A. Hayek, Law, Legislation and Liberty (London 1982), especially ch. 17. 
contain a bill of rights that would enable judges to control the acts of legislatures. Such a provision may well be sensible in some societies, but it is far from obvious that it would be sensible in all. ${ }^{37}$ Though we may be reluctant to concede to Montesquieu that the national climate can help structure the constitution, ${ }^{38}$ it is certainly the case that geography, religion and ethnic division can shape the division of power within a particular country. A bill of rights will not be ideal for all societies. In some systems the judges may have a poor history of protecting citizens' rights, perhaps favouring the rich and powerful over the poor and weak. In other systems ethnic divisions may mean that it is only through compromises thrashed out in a representative forum that violence can be avoided. ${ }^{39}$ On the other hand, in other societies the identical concern may create a need for the courts to protect minorities, using a bill of rights to protect the weaker group. ${ }^{40}$ It is not only ethnic division that can impact on the constitution; geography can also shape the powers that ought to be allocated to institutions. For instance, the size of the United States means that a considerable degree of de-centralisation is required; even the court structure is fragmented. ${ }^{41}$ In a smaller country the problems of such diversity would far outweigh its advantages.

If the goal of the separation of powers is the promotion of efficiency, there seems little reason to attempt to confine the doctrine within the straight-jacket of the three classic branches of state: the legislature, the judiciary and the executive. ${ }^{42}$ The simplicity and intuitive appeal of this divide has encouraged a surprisingly high level of support from writers on constitutional law, but whilst this division may have been defensible in the time of Montesquieu it cannot be defended in the modern age. The divide collapses in two ways. First, modern institutions increasingly possess powers drawn from two or more of the classic separation of powers trinity; overlap and confusion is significant and desirable. Secondly, it is simply unhelpful to think of the institutions of state

${ }^{37}$ Hayek does acknowledge that in countries with a long established constitutional structure his dictates may not hold: ibid., at pp. 107-108.

38 Montesquieu, Spirit of the Laws, Part 3 Bk. 14.

39 Though ethnic divisions can not be legislated away, it may be possible to create deliberative forums through which debate can be constitutionalised. See J. Waldron, Law and Disagreement (Oxford 1999), at pp. 73-74; D. Horowitz, Ethnic Groups in Conflict (California 1985), ch. 15; A. Lijphart, Democracy in Plural Societies (New Haven 1977); S. Smooha and T. Hart, "The Diverse Modes of Conflict Regulation in Deeply Divided Societies" in A.D. Smith (ed.), Ethnicity and Nationalism (New York 1992).

40 A. Lipjhart, Patterns of Democracy (Yale 1999), at pp. 32-33.

${ }^{41}$ H. Jacobs, in H. Jacobs, E. Blankenburg, H. Kritzer, D. Provine and J. Saunders, Courts, Law and Politics in a Comparative Perspective (New York 1996), at pp. 7 and 33.

42 Ackerman (2000) 113 Harv.L.Rev. 633, at pp. 724-725. 
in monolithic terms; all three of the grand branches of state collapse.

The line between the three branches of state has become increasingly blurred; modern institutions often span two or three of Montesquieu's categories. In the European Union, for example, the Commission plays a part in legislative, judicial and executive activities. ${ }^{43}$ The Commission has a wide power to create law in cooperation with other European institutions, and in some circumstances has unilateral legislative power. The Commission also has an executive role: it seeks to ensure that directives are correctly applied within Member States, and plays a part in the policing of state compliance with European law. It can also investigate alleged breaches of competition and anti-dumping rules by private bodies. This leads on to the Commission's judicial role: having investigated apparent abuses by member states and private companies, the Commission is empowered to make preliminary judgements as to their guilt and to issue fines. This mix of powers is not merely the limited overlap advocated by those who believe in the importance of "checks and balances" between institutions. It is a complete redrawing of Montesquieu's division of the state. The powers of the Commission may ${ }^{44}$ be justified by the unique set of tasks it has to perform. It has to hold the Union together; both by forwarding Community policy and by heading off conflicts between the Member States and the European Institutions. ${ }^{45}$ It would seem odd if the separation of powers did not also apply to this institution; the European Commission has a significant, if disputable, place within the British Constitution. This sort of overlap, though on a more moderate scale, is also obvious within national systems. ${ }^{46}$ The failure of the three branches of government to maintain their integrity under examination is matched by the ease with which functions can change hands: devolution in Wales was confined to those powers previously held by the executive. A legislature was established in order to decide on what had previously been matters of administrative discretion. ${ }^{47}$

The three great monoliths of the state: the executive, the legislature, and the judiciary collapse under the slightest of pressure. It is rare to find a modern state with a single legislature,

${ }^{43}$ P. Craig and G. de Búrca, EU Law Text Cases and Materials, 2nd ed. (Oxford 1998), at pp. $50-57$.

44 This article is not the place for a defence of, or an attack upon, the scope of the power given to the Commission.

${ }^{45}$ J. Fitzmaurice, "The European Commission" in A. Duff, J. Pinder and R. Pryce, Maastricht and Beyond (London 1994), at p. 181.

46 Jennnings, note 9 above; S.A. de Smith and R. Brazier, Constitutional and Administrative Law, 8th ed. (London 1998), at p. 18.

47 The Government of Wales Act 1998. 
or indeed a single judicial system. Modern states typically contain many inter-linked legislative bodies. In Britain legislative power has been devolved down to the regions, and transferred up to Europe. In the United States legislative institutions exist both at the federal and at the national level. The judicial structure may also be blurred. There is competition between administrative forms of adjudication, such as ombudsmen, tribunals and inquiries, and the courts. There may also be competition between the courts themselves. $^{48}$ The executive collapses most easily of all. In the separation of powers trinity this notion principally seems to exist to capture all that is excluded from the other two categories. ${ }^{49}$ There really seems little to bind the various elements of the executive together; in the United Kingdom the politically impartial civil service has little in common with their elected masters, the police bear little similarity to the law officers.

Abandoning the tripartite vision of the state strengthens the doctrine of separation of powers. The doctrine is as concerned with the proper allocation of competence between competing legislatures as it is with the balance between a legislature and a court. ${ }^{50}$ It need not be confined to states at all; supra-national courts and legislatures are also within its scope. It is hard to see why writers on separation of powers are so willing to allow these questions to be pushed into the background; if, for example, it is the purpose of the constitution to protect liberty then the allocation of power to competing legislatures may be of considerable significance. Indeed, ignoring alternative methods of dividing power can create a dangerously misleading picture of the constitution. The presence or absence of divisions of power in the vertical axis, as, for example, is found in federal states, must impact on the optimal division of powers between institutions on the horizontal axis. Separation of powers is a vigorous, contemporary doctrine that recognises the central importance of institutional choice in constitutional writing.

\section{Separation of Powers: General Considerations}

Separation of powers is a distinctively constitutional tool. It addresses itself to the authors of the constitution; it enjoins them to match function to form in such a way as to realise the goals set for the state by political theory. Having decided that a particular goal

\footnotetext{
48 N.W. Barber "Sovereignty Re-examined: The Courts, Parliament and Statutes" [2000] O.J.L.S. 130; I. Canor, "Primus inter pares. Who is the Ultimate Guardian of Fundamental Rights In Europe?" (2000) 25 E.L.Rev. 3.

49 Ackerman (2000) 113 Harv.L.Rev. 633, at p. 691.

${ }^{50} \mathrm{On}$ this point, see the broader interpretation of the separation of powers advanced by Hayek, note 37 above, at p. 104.
} 
ought to be striven after in a society, the doctrine then focuses our attention on the manner by which it may be achieved. ${ }^{51}$ At this stage in the article the political assumptions that lie behind the broad understanding of the separation of powers must be thickened up. Whereas in the earlier part of the article all that was assumed was the thin assumption that powers should be allocated to the institution which was best placed to execute them, further assumptions must now be made about what factors may make an institution good at undertaking certain tasks. Again, though, these assumptions are weak ones. They merely indicate issues of significance, they do not necessarily require the prioritisation of one factor over the others. Separation of powers encourages us to consider various interconnected structural factors that affect the competency of institutions in the performance of their tasks. First, the composition and skills of an institution must be examined: the knowledge and experience of the actors within it. Secondly, the scope of the institution's information-gathering powers may be of interest; some bodies are better than others at gathering different types of information. Thirdly, the manner of the institution's decision-making process may be significant; some issues may lend themselves well to expert decision-making, others will be better allocated to amateur processes which have the virtues of openness and inclusivity. This point leads on to a fourth consideration: the vulnerability of the institution to outside pressures. Whether this is considered an advantage or a danger will depend both on the particular issue before the decision-maker and on our understanding of the nature and importance of citizens' participation in decision-making. As this fourth consideration shows, this thin understanding of separation of powers rests on a slippery slope. These structural concerns obviously relate to deeper issues of legitimacy, and drag us towards richer, thicker, normative theories involving rights and democracy. These issues are as relevant to a full vision of the separation of powers as the structural issues that have just been raised, and elide into them. However, there is profit in holding back from descending into a full normative theory. By focusing on these relatively uncontroversial factors we can outline reasons for and against the attribution of functions that will exist within all understandings of the separation of powers, but it must not be forgotten that these reasons are not strong enough in themselves to provide a conclusive answer to the question of attribution of function. They will just be one reason amongst others, and their strength will depend on the particular

${ }^{51}$ Neil Komesar addresses similar issues in Imperfect Alternatives (Chicago 1994), an outstanding work of institutional analysis. 
circumstances of the discussion and the power of the other, countervailing, reasons.

It would be wrong to assume, as the previous paragraph might appear to, that institutions can be identified separately from the tasks that they perform. There is no natural set of state institutions which exists prior to the state. The identity of an institution is partly fixed by its structure, but also partly by the tasks it performs. For instance, courts are distinguished both by their form and by their function. The structure of the court is, more or less, triadic: ${ }^{52}$ a confined number of judges deciding between two rival positions. The function of the court is conflict resolving; it brings closure to disputes. These two aspects of what a court is cannot be divided. Whilst separation of powers is concerned with the allocation of function to form, these two elements are often indissolubly linked. Sometimes it is not possible, or not sensible, to allocate a new task to pre-existing institutions; a new structure must be created to accommodate the task. Separation of powers is not therefore just a theory about the division of powers, it is also concerned with the creation of institutions. A further complexity is occasioned by the symbiotic relationship between form and function. As function follows form, so too does form follow function. ${ }^{53}$ An institution will naturally adapt to accommodate the tasks allocated to it. For instance, in the United States much of the legislation enacted by Congress is drafted by the House and the Senate. This presents a sharp contrast with most constitutions in which legislation is drafted by the executive and then set before the legislature for approval. However, the oddity is less pronounced when the law making methods of Congress are examined more closely. Draft legislation that is put before the House of Representatives and the Senate normally has its origins in committee deliberation. ${ }^{54}$ These committees have no direct counterpart in the British system. ${ }^{55}$ The committee structure alleviates, even if it does not cure, some of the deficiencies of the legislature drafting legislation. ${ }^{56}$ In order to fulfil the tasks entrusted to it, the structure of Congress has changed. ${ }^{57}$ Similarly, an institution will seek to acquire tasks that it believes that its form makes it well equipped to under-take. For instance, in the United Kingdom the courts have steadily expanded their control over

\footnotetext{
52 M. Shapiro, Courts: A Comparative and Political Analysis (Chicago 1981), ch. 1.

53 E. Rubin, "The New Legal Process" (1996) 109 Harv.L.Rev. 1393, at p. 1428.

54 N. Bowles, Government and Politics of the United States, 2nd ed. (London 1998), ch. 7; M. Vile, Politics in the USA, 5th ed. (London 1999), at pp. 116-118.

55 K. Bradshaw and D. Pring, Parliament and Congress (London Rev. ed. 1981), ch. 5.

56 This point is discussed in more detail later.

57 Ibid., at pp. 210-212.
} 
regulatory agencies. The judges regard the activities of these agencies as being "court-like", 58 and therefore inherently within their competency. They are unwilling to see this task fulfilled entirely outside of the court structure. ${ }^{59}$

These concerns should make us very cautious about trying to expound any abstracted account of the separation of powers. The following section will, very cautiously, attempt to put forward some general considerations centring on the idea of efficient allocation of function to form. It will examine the structure of the courts and the legislature and ask whether their structures generate any reasons to attribute functions to these institutions. The exercise will begin to reveal the central truths that are contained within much writing on the separation of powers; why there is a natural link between the institutions of the judiciary and the legislature and the judicial and legislative function. None of these remarks will necessarily provide a complete argument for or against the allocation of a function to an institution. To show that one body is not well equipped to perform a task is not a reason to switch that task to another body. Even if, in the abstract, the courts are badly placed to undertake a task it does not follow that the legislature, or the market, will do any better. ${ }^{60}$ The most that can be accomplished in the following sections is to provide considerations that have general application to societies that possess courts and legislatures.

\section{A. The Courts}

The first, and the most obvious, structural point that can be made about the courts is their triadic form. Martin Shapiro has claimed that this is central to the nature of a court: a judge, or judges, adjudicating between two rival parties. ${ }^{61}$ Though this model is deviated from in interesting and significant ways, there seems to be a core truth to the description: institutions adopting this form can be found in almost all societies and cultures. The judge acts as representative of the state or community and provides the disputing parties with a forum in which their disagreement can be resolved. One of the most notable features of the court system is the limited number of the adjudicators who sit on each case. It is rare to find a court with more than a dozen judges, and generally it seems that

${ }^{58}$ I avoid the loaded term "quasi-judicial".

${ }^{59}$ See, for example, R. v. Parliamentary Commissioner for Administration, Ex p. Dyer [1994] 1 All E.R. 375; Bushell v. Environment Secretary [1980] 2 All E.R. 608; R. v. Medical Appeal Tribunal, Ex p. Gilmore [1957] 1 Q.B. 574 Anisminic v. Foreign Compensation Commission [1969] 2 A.C. 147 and R. Cooke, "The Struggle For Simplicity in Administrative Law" in M. Taggart (ed.), Judicial Review of Administrative Action in the 1980s (Oxford 1986), at p. 10.

${ }^{60}$ Komesar, Imperfect Alternatives, at p. 104; D. Horowitz, The Courts and Social Policy (California 1977), at pp. 18, 24.

${ }^{61}$ Shapiro, Courts, ch. 1. 
there are between one and three judges in the court. ${ }^{62}$ It follows from this that it is virtually impossible for a single judge to hear all the cases arising within a system. There will, almost unavoidably, be a multiplicity of judges. This creates dilemma for those appearing before the courts; how can they be certain that the outcome of their case will not depend on the selection of the judge? Montesquieu proposed two remedies for this fear. First, the judges should be drawn from the people by lot; by this method the dangers of the agglomeration of power in the hands of a professional judiciary would be avoided, preventing the judges from imposing their own ideologies on the law. Secondly, the judges should be confined to the application of law; if courts were to allow judges to decide cases according to their own view of the merits it would be impossible for anyone to know her legal position before going to court. ${ }^{63}$ These two protections are in conflict. Once society passes a certain level of development the laws become unavoidably complex. If consistency is desired in the application of the law the existence of a professional, trained, judiciary is vital: the time and effort taken up by this training unavoidably restricts the extent of the judges' non-legal skills. The structure of the court as a decision-making body presents us with a stark choice. If we value consistency we must create a professional group of judges, trained in the application of the law. However, such a group will, inevitably, know little of much else; they will not have the broad experience of life that comes of undertaking non-legal jobs. The greatest strength, and the greatest weakness, of a professional judiciary is its detachment from those it passes judgment upon. Consistency is fostered at the cost of understanding.

A second structural point about the court system is its reliance on the parties before the court. The triadic structure is premised on the consent of at least one of the parties to the adoption of the court as a conflict-resolving forum; even in criminal proceedings the court cannot proceed without the state bringing a prosecution. It is implausible to imagine a system in which parties were compelled to bring their cases before the court; the state can not expose a dispute where the parties are not willing to admit their differences. ${ }^{64}$ Two consequences flow from this. First, the court will not hear cases where the parties to a dispute either do not wish, or are not

${ }^{62}$ The question of unusually large courts is addressed later in the article.

${ }_{63}^{63}$ Montequieu, Spirit of the Laws, Bk. 11, ch. 6.

${ }^{64}$ Contrast K. Llewellyn and E. Hoebel, The Cheyenne Way (Oklahoma 1941), at p. 48, cited in L. Fuller, "The Forms and Limits of Adjudication" (1978) 92 Harv.L.Rev. 353; Shapiro, above Courts, at p. 13. As with all the comments made in this section there may be qualifications to be made in some circumstances: for instance, when a settlement is made in a dispute involving a minor or an incapacitated person the court may demand the right to approve the agreement. 
able, to bring the case before the court. Secondly, the court's understanding of the case is largely confined to the submissions of the litigants before it; other interested parties may not be heard.

These two structural points about the skills and the nature of the courts have important implications for the tasks that should be assigned to them. The ability of a court declines as the tasks it undertakes deviate from the triadic model.

First, there are certain types of issue that that cannot be satisfactorily resolved in the triadic model because the decision has implications that go beyond the parties appearing before the judge. This point is not a new one; Lon Fuller characterised such issues as "polycentric" ${ }^{65}$ An issue is a polycentric one when it is interrelated with other issues. Fuller used the analogy of a spider's web: when one strand is plucked the whole web changes. ${ }^{66}$ For instance, a decision that has the effect of raising the price of aluminium will also affect the price of steel, wood, cars and the cost of hiring a taxi. The decision of the court consequently has an impact on parties who may not be represented before the judge; he does not have a full understanding of the decision he is making. Because the judge is confined to the evidence put by the parties before him, his knowledge of the impact of the decision on others is likely to be sketchy. Even if he is aware of the broader implications of his action it is unlikely that he will be able to accommodate these factors in his decision. An understanding of these consequences would require the judge to have knowledge of the particular industry or group that he is unlikely to possess. Whilst the parties within the triadic form can be relied upon, up to a point, to tell the judge all he needs to know about their interests in the matter, they can not be relied upon, nor be expected, to inform him about the decision's collateral effects. ${ }^{67}$ Polycentricity is a matter of degree ${ }^{68}$ Most decisions before the court have some elements of polycentricity about them; court action can rarely be contained within a neat boundary between the parties. ${ }^{69}$ It may be impossible for a court, or indeed for anyone, to know in advance how far the implications of a decision before the court will spread. Polycentricity is often unpredictable; the court will not always be aware of the extent of its ignorance. ${ }^{70}$ The more polycentric a

\footnotetext{
${ }^{65}$ L. Fuller, note 64 above; see also R. Bone, "Lon Fuller's Theory of Adjudication and the False Dichotomy Between Dispute Resolution and Public Law Models of Litigation" (1995) 75 Boston U.L.Rev. 1273, at p. 1314 onwards; Horowitz, Courts, at pp. 30-33.

${ }^{66}$ Fuller, (1978) 92 Harv.L.Rev. 353, at p. 395.

${ }^{67}$ Komesar, Imperfect Alternatives, at p. 125.

${ }^{68}$ Fuller (1978) 92 Harv.L.Rev. 353, at pp. 397-398.

69 J. Allison, "Fuller's Analysis of Polycentric Disputes and the Limits of Adjudication" (1994) 53 C.L.J. 367 , at p. 372

${ }^{70}$ Ibid., at p. 372.
} 
question is, the harder it is to answer it satisfactorily within the triadic structure.

The method that the courts use to resolve disputes also reduces their capacity to accommodate polycentricity. Courts decide disputes between the parties; each case is treated separately. They are not able to create a solution that applies far beyond the particular case before them. Whereas a legislature can provide a relatively comprehensive scheme for the resolution of disputes within an area, the courts are compelled to proceed on a case by case basis. ${ }^{71}$ Judges are well placed to correct discrete anomalies in the laws that affect confined groups of individuals. They are less able to impose systemic solutions that change an area of law. Their decisions lack the unity of purpose that a statute can bring.

Secondly, the dependence of the court upon the parties involved in a dispute also provides an inherent limitation on the type of tasks that can be entrusted to the court model. ${ }^{72}$ There are certain areas of activity that the courts will be poorly equipped to control, simply because the parties concerned are unlikely to bring disputes before the courts. There are two factors that may cause parties to fail to bring their cases before the court: poverty of resources and lack of interest in the outcome. These two factors restrict the court in several ways. They form a natural limit on the ability of the court by restricting the disputes that come before the judge. They may also feed back into the problem of polycentricity: some parties with an interest in the dispute may not be able to raise their concerns within the court system.

A party suffers from poverty of resources when it wishes to bring a case before the court but lacks the strength to do so. Most commonly this will be because of financial constraints; the plaintiff simply lacks the money to get the case into court. This problem can be mitigated by the provision of legal aid, but it is unlikely that it can ever be completely overcome. A further, more difficult, resource problem arises from unequal power relationships. When two parties are in a continuing relationship it may be impossible for the weaker party to bring the abuses of the stronger before the court; fear of reprisals may prevent free access. This phenomenon is widespread. It can occur within family relationships and within commercial relationships. Wives may be unable to gain the protection of the law against abusive husbands, children may be left at the mercy of their parents. In business similar patterns can be discerned: a weak distributor is unable to assert its legal rights against a powerful supplier, the small franchise-holder is unable to

${ }^{71}$ Horowitz, Courts, at pp. 35-38.

72 Komesar, Imperfect Alternatives, at pp. 125-134. 
challenge the conduct of the large franchise-giver. Going to court is rarely an option for such parties; they can only vindicate their legal rights at the expense of the relationship. Judges will find it very hard to impose legal rules on such relationships simply because disputes within these relationships so rarely come before the court. Even the rules that are laid down may not be followed by the more powerful party within the relationship. Judges are good at regulating one-off relationships between parties of equal strength; they are less proficient at regulating on-going relationships between parties of differing strengths. It is unsurprising, though inexcusable, that the English law of obligations has traditionally striven to avoid admitting the significance of continuing relationships. Classical contract and tort law both tend to model themselves on isolated transactions between parties of equal strength.

A further restriction on the parties appearing before the court is a lack of interest in the outcome of the proceedings. Sometimes the impact of an action is so widely diffused that none of the individuals affected by it is sufficiently concerned to bring the issue before the court. Nevertheless, the impact of the action could be extremely significant for society as a whole. The polluter who pumps smog over a city, or the television station which broadcasts violent movies, may have caused tangible harm to many people without any one of those persons having sufficient interest to bring a case before the courts. The converse situation may also hold: where lots of polluters are harming the air quality, or lots of broadcasters broadcast violent films, an individual may be harmed as a result of these cumulative acts, but not be able to show that any one actor has played a significant role in causing the harm. One way in which these problems may be alleviated is by allowing interest groups to bring cases on behalf of those affected. This is only a partial solution. ${ }^{73}$ First, it does not resolve the problem of diverse actors harming an individual. Secondly, there is no guarantee that interest groups will necessarily arise where needed. Thirdly, there are problems inherent in interest group representation. It is difficult to ensure that the group really does represent the public interest and not merely one unchallenged strand of it. The problem of polycentricity rises again.

Fuller thought that the courts ought to shy away from answering polycentric questions because they were not structurally equipped to resolve such disputes. ${ }^{74}$ However, just because the

\footnotetext{
${ }^{73}$ See E. Elhauge, “Does Interest Group Theory Justify More Intrusive Judicial Review?” (1991) 101 Yale Law Journal 31, who argues that interest groups that are a weak force in society will also be a weak force before the courts. Contrast T. Merrill, "Does Public Choice Theory Justify Judicial Activism After All?" (1997) 21 Harvard Journal of Law and Public Policy 219.

${ }^{74}$ Fuller (1978) 92 Harv.L.Rev. 353, at p. 371.
} 
judges are not well placed to provide an answer it does not follow that another institution within the state would do a better job. ${ }^{75}$ Sometimes the court may be the least bad alternative; the benefits of a swift decision may out-weigh the costs of delay. The desegregation case in the United States provides an example of a situation where the arguments for speedy action, already shockingly delayed, outweighed the institutional reasons against judicial intervention. Even though the judicial process was ill equipped to combat segregation, indeed its rulings were for a time unenforceable, ${ }^{76}$ the plain justice of the cause demanded action. ${ }^{77}$ Desegregation would have been better effected through statutory and executive action, which could have provided a comprehensive and enforceable solution to the problem; such a solution, however, was not immediately forthcoming. ${ }^{78}$ Secondly, sometimes the question may fall to the court simply because no other institution is willing to face up to the problem beyond agreeing that something must be done. For instance, the formulation of competition law has remained the province of the judges both in Europe and in America. ${ }^{79}$ Though there is political agreement that regulation is needed, there is no consensus as to the detailed course of action to be pursued. There are various ways in which the structure of the courts and the law can try to compensate for the inherent limitations of the triadic model, some of which will be briefly examined in the next section. However, such accommodation will always be less than ideal; the functions entrusted to the court will be in conflict with its form. This conclusion reflects some of the contentions contained in traditional writings on separation of powers. Adopting the weakest sensible normative stance, a link can be drawn between the institution of the judiciary and the function of exercising judicial power. The court, and the judges, are strong when faced with issues that can be contained within the triadic model, they become weaker as this model is departed from. They are particularly well-placed to decide discrete disputes between parties that are regulated by pre-existing law. Their competence is placed under pressure as they move from this task towards the broader goal of setting social policy.

\footnotetext{
${ }^{75}$ Komesar, Imperfect Alternatives, at p. 204.

${ }^{76}$ H. Abraham and B. Perry, Freedom and the Court, 7th ed. (Oxford 1998), at p. 354.

77 Fuller approved of the desegregation cases despite the obvious implications of polycentricity. See Allison (1994) 53 C.L.J. 367, at p. 374, citing a letter of Lon Fuller to Frank Newman on 22 October 1959.

78 J.H. Choper, Judicial Review and The National Political Process (Chicago 1980), at pp. 152153.

${ }^{79}$ Fuller (1978) 92 Harv.L.Rev. 353, at p. 373. The Sherman Act and the EC Treaty seem wilfully vague.
} 


\section{B. Deviant Courts}

"Deviant" should not be taken to imply that such courts act improperly, or are in some sense inferior to other courts, merely that their functions have led them to be structured in a manner which is significantly different to the basic triadic model set out above. The phrase is also used to distinguish this discussion from Fuller's account of "mixed" institutions. ${ }^{80}$ In some instances the court has been established with an unusual structure, in others it has adapted its structure to fulfil functions that it regards as having been left unfulfilled by the other institutions of the state. These deviant courts illustrate the complex links between form and function. Their departure from the triadic model is necessitated by the functions that they attempt to fulfil.

First, there are those courts that are unusually large. The triadic model conjured images of a single judge facing two parties. In some courts the number of judges exceeds the number of litigants; occasionally by a considerable margin. In the English legal system the number of judges tends to increase as the case moves up the court hierarchy. Though this is a common feature of many legal systems it is surprisingly hard to explain. Why should it be thought that three or five judges are more likely to reach a correct legal conclusion than one? There appears to be a link between the size of the court and the level of activism that it feels able to exercise: the more power the court wields the larger it becomes. When the House of Lords found itself in the embarrassing and unprecedented position of reviewing one of its own decisions for bias, seven judges sat rather than the usual five. ${ }^{81}$ Though the explanation for this is rarely made explicit, it seems that the larger size of the court adds to the perceived legitimacy of the decision. This added legitimacy cannot be democratic; though the result may end up turning on a majority vote the judges do not act as delegates of the people in any meaningful sense. Perhaps the answer can be seen in the great trans-national court of the European Union and of the European Convention on Human Rights; the European Court of Justice and the European Court of Human Rights are conspicuously large. The European Court of Justice normally sits with nine judges, though in controversial cases a full bench of 15 may sit. ${ }^{82}$ The Grand Chamber of the European Court of Human Rights consists of 17 judges. In both cases the nationality of the judges is regarded as exceptionally important; each member state has a right to submit

${ }^{80}$ Ibid., at pp. $406-407$.

${ }^{81}$ R. v. Bow Street Magistrates Court, Ex p. Pinochet Ugarte (No. 2) [2000] 1 A.C. 119.

${ }^{82}$ Craig and de Búrca, European Law, at pp. 78-86. 
candidates. Part of the rationale for large courts is undoubtedly political; it makes the decision of the court more palatable to those before it. Trans-national courts are especially sensitive to the need to secure acceptance; their authority depends on the voluntary obedience of member states. The same explanation does not seem to hold for large national courts. Perhaps a second explanation for the size of the court lies in the concept of polycentricity. Larger courts tend to be more activist, they tend to have quite a large amount of freedom to shape the law to fit with their conception of social policy. This is especially true of the European Court of Justice and the European Court of Human Rights where the documents that fall to be interpreted seem wilfully vague. Given this, the narrow legal skills of distinguishing cases and construing statutes are less useful to these higher courts than to their inferior counterparts. The task of these courts in shaping the law to fit with social policy necessitates sensitivities beyond the understanding of law. ${ }^{83}$ The ideal member of one of the larger courts has political and practical knowledge of his society. He must be aware of the impact of his decision on the political process and on society in general. When making a decision about the need for consideration in contract formation, for instance, the judge must consider the impact of the decision on industry, and the propriety of the court, rather than Parliament, altering this rule of law. The more judges that sit, the higher the chances that one of them will have had some experience of the area of life under consideration. Similarly, in the trans-national courts the insistence that judges be drawn from all the countries affected by the decision could be seen as an attempt to ensure that the court has as much experience as possible of the probable impact of its decision within the national states. Perhaps it is hoped that the more judges that sit on a case, the more likely it is that their collective expertise will serve to mitigate the problems of polycentricity? However, this comfort is largely illusory. There is no guarantee that a member of the panel will have the needed expertise to counter polycentric concerns; the insistence that the judges be lawyers, though understandable, makes homogeneity more likely than diversity.

Secondly, some courts include lay-members in addition to a legally trained judge. A good example of a mixed bench can be found in the system of Employment Tribunals in the United Kingdom. The Employment Tribunals sit in benches of three. One of the judges is a lawyer, the second a trade union representative and the third a representative of business. Part of the reason for

${ }^{83}$ Shapiro, Courts, at pp. 35-36, describes the adversarial form of such proceedings as a "facade". 
this unusual structure was an attempt to gain the acceptance of the parties involved in litigation; previously the courts had been perceived as favouring the employers over employees. ${ }^{84} \mathrm{~A}$ second justification of this structure is that a tripartite bench helps alleviate the problems of polycentricity by broadening the experience and expertise of the judges. ${ }^{85}$ The composition of the Tribunal gives it a wide understanding of industry and the workings of labour relations. The Tribunal moves away from the court structure towards a deliberative institution; an institution with the skills and knowledge to decide on what constitutes the best industrial practice in any given situation. However, the departure from the triadic model comes at a price. The Employment Tribunal is attempting to be both a court-like institution that applies the law, and a deliberative institution that decides what the rules governing labour relations ought to be. Though all courts, to a greater or lesser extent, have this dual function, the Employment Tribunal is unusual in that its position as a court of first instance should encourage it to adopt a low level of judicial activism $^{86}$ yet its composition encourages a high level of freedom. ${ }^{87}$ Unsurprisingly, these two structural features manifest themselves into a direct conflict between the value of consistency and the utilisation of the specialist knowledge of the lay-members. Cases and writers oscillate between valuing predictability over discretion, ${ }^{88}$ and discretion over predictability. ${ }^{89}$ There is no way in which the Employment Tribunal, as a court of first instance, can ever hope to strike an entirely satisfactory balance between these two goals.

Thirdly, it is possible for a court deliberately to depart from the triadic structure in order to combat the resource deficiencies of litigants. An interesting example of this can be found in India where the Supreme Court has attempted to meet the institutional challenges posed by a combination of a weak legislature and an extremely poor citizenry. The Supreme Court has relaxed the formal restrictions on applications to the court. An application can be

${ }^{84}$ P. Davies and M. Freedland, Labour Legislation and Public Policy (Oxford 1993), at p. 394. Contrast the position in the United States: Shapiro, Courts, at p. 19.

${ }^{85}$ I. Smith and G. Thomas, Industrial Law (London 1996), at p. 334. For similar reasons the French administrative court includes former civil servants amongst the judges.

${ }^{86}$ Because it cannot make general changes in the law which will be of broad application, as can, for example, the House of Lords.

${ }^{87}$ This is recognised by the judges: Gilham v. Kent District Council (No. 2) [1985] I.C.R. 233, esp. pp. 240 and 244. See generally, Smith and Thomas, Industrial Law, at pp. 339-347.

${ }^{88}$ For example, Naylor v. Orton and Smith Ltd. [1983] I.R.L.R. 233, at 237, N. BrowneWilkinson, "The Role of the EAT in the 1980s" [1982] I.L.J. 69.

${ }^{89}$ For example, Bailey v. BP Oil (Kent Refinery) Ltd. [1980] I.C.R. 642, Philips "Some Notes on the Employment Appeals Tribunal" [1978] I.L.J. 137. 
made by a letter, or even a postcard, addressed to the court. ${ }^{90}$ Standing has been liberalised to allow challenges to government acts by persons other than those who have suffered from it, allowing social reformers and investigative journalists access to the courts. ${ }^{91}$ In some situations the court will commence a case without any plaintiff at all; in one case a newspaper story that blind girls were suffering sexual abuse by their teachers triggered the court into action. ${ }^{92}$ In the absence of an empowered plaintiff, the Court may take it upon itself to investigate complaints; appointing officers to act on its behalf. ${ }^{93}$ These measures must be commended as a significant attempt to adapt the court to the needs of the unempowered citizenship, but whilst this may be the best of all possible alternatives it remains a far from ideal solution. Though the court is able to mitigate the limitations of its structure, it cannot wholly escape them. The court lacks the resources to ensure that its orders have been followed, ${ }^{94}$ and there is a risk that the court's increasing involvement in social policy will lead it to stray far beyond the area of its expertise. ${ }^{95}$ Further, the protection provided by the court for the poor cannot hope to be comprehensive; relaxing standing and access to the court can not ensure that all abuses will be brought to the attention of the judges. ${ }^{96}$

There are many other structural deviancies that could be discussed. Indeed, this article has deliberately avoided one of the main devices used by the courts to resolve the problems of polycentricity: the encouragement of mediation. For the purposes of this essay this phenomenon is not very significant; it is an example of where the courts recognise the limitations that their structure places upon them, and have entrusted the function to an alternative institution. ${ }^{97}$ This section has aimed to demonstrate the ways in which courts can be adapted, or can adapt, to meet some of the limitations of the triadic model when their tasks force them beyond

90 Sunil Batra v. Delhi AIR 1980 SC 1579; Kadra Pehadiya v. Bihar AIR 1981 SC 939; H. Seervai, Constitutional Law of India, 4th ed. (Delhi 1993-1997), at pp. 1822-1824; S. Sathe, Administrative Law, 5th ed. (Delhi 1994), at pp. 383-384.

91 S.P. Gupta v. Union of India AIR 1982 SC 149; P. Craig and S. Deshpande, "Rights Autonomy and Process: Public Interest Litigation in India" [1989] O.J.L.S. 356.

92 Pratul Kumar Sinha v. Orissa AIR 1989 SC 1783; Sathe, Administrative Law, at pp. 385-386.

93 S.P. Gupta v. Union of India AIR 1982 SC 149; Craig and Deshpande [1989] O.J.L.S. 356, at pp. 363-364.

94 Sathe, Administrative Law, at p. 389; Shapiro, Courts, at p. 15; Choper, Judicial Review, at p. 139; M. Tushnet, Red, White and Blue: A Critical Analysis of Constitutional Law (Harvard 1988), at p. 198.

95 Sathe, Administrative Law, at p. 387.

96 Horowitz, Courts, at pp. 51-56; M. Galanter, "Missed Opportunities: the Use and Non-use of Law Favourable to Untouchables and Other Specially Vulnerable Groups" in M. Galanter, Law and Society in Modern India (Oxford 1997); C. Epp, The Rights Revolution (Chicago 1998), ch. 6.

97 Shapiro, Courts, ch. 1. 
the confines of that structure. It has also endeavoured to demonstrate the strains that are caused when the courts seek to act in cases removed from the triadic model; strains that may, in the hard reality of specific constitutions, be unavoidable. ${ }^{98}$

\section{The Legislature}

Much has been written on courts as a general phenomenon, very little has been written about legislatures abstracted from particular constitutions. ${ }^{99}$ This is a surprising omission. Legislatures are a feature of almost all constitutions; but their strength, and therefore to an extent their function, depends greatly upon the particular constitutional framework of the state. The comments that can be made about the link between the structure of the legislature and its functions are also weakened by the diversity of structures contained within the concept of a legislature. Whereas the triadic model seems to be at the core of our understanding of what a court is, legislatures are far more diffuse. The size and composition of legislatures varies widely. The impact of political parties, committees, the presence or absence of a cabinet system, and even the methods by which voting is undertaken impacts on the structure of the legislature ${ }^{100}$ and so on the tasks which it can undertake. Most modern writing on legislatures focuses on the differences between institutions rather than the qualities they share. ${ }^{101}$ Any general structural comments about the legislature must be treated with extreme caution.

The first structural point that may be made about legislatures is that they tend to be fairly large. Wheare estimated that most lower houses range from around one hundred to about three hundred members. ${ }^{102}$ The House of Commons consists of 659 members and so is unusually large. The size of chambers ensures that they will include a considerable range of different opinions and experiences. On any given topic it is likely that the chamber will include a number of people with some understanding of the issue being debated. This will often mean that the chamber contains the expertise to produce an informed debate about the topic. However,

${ }^{98}$ Komesar, Imperfect Alternatives, at p. 204.

99 P. Norton, "Introduction" in P. Norton (ed.), Legislatures (Oxford 1990), at 8-9; though see J. Waldron, Law and Disagreement (Oxford 1999) and J. Waldron, The Dignity of Legislation (Cambridge 1999). Waldron's premises, resting on understandings of democracy and legitimacy, and the conclusions he draws from them, are stronger than those advanced here. That neither his premises nor his conclusions figure in this section should not be taken as agreement or disagreement with them.

100 See, for example, the cautious submission of Wheare that even the seating within the legislature can affect the way which the body works. Presumably this would have an impact on its ability to undertake certain tasks: K. Wheare, Legislatures (London 1963), at pp. 8-14.

${ }^{101}$ See, for instance, Lipjhart, Patterns.

102 Wheare, Legislatures, at p. 5. 
the experts within the legislature will normally be in the minority. Though the debate may be informed, those who vote on the resolution are not required to demonstrate any expertise. The size of legislatures makes it likely that someone within the chamber will know something about the issue being discussed; it also makes it probable that he will be in a minority.

This consideration takes us on to a second structural point that can be made about legislatures: their amateur nature. Though some members of the legislature may possess specialist knowledge relevant to the question before them, the majority almost certainly will not. The amateur nature of the legislature is seen as one of its strengths; it is a collection of individuals who are, in some significant way, linked to the population of the country. It would be regarded as odd if only those members who really understood the subject of debate were permitted to speak about it; odder still if members were only entitled to vote on matters within their expertise. The legislature is not primarily a forum for arguments between experts, though expert argument may be presented to the chamber. The structure of the legislature is such that expertise is controlled; the expert must try to convince his amateur fellows of the strength of his position.

These structural comments have functional implications. ${ }^{103}$ The legislature is a good forum for enabling representatives of the population to test expert opinion. It is a bad forum for the initial formulation of expert opinion. When Mill described the Commons as a "Congress of Opinions" 104 he did not intend the phrase to be taken pejoratively. One of the most useful functions of a legislature is to discuss and challenge proposed legislation and the policy decisions of the executive. The experts, in the shape of the government, are forced to justify and explain their actions to the amateur chamber. The small number of experts within the chamber facilitate this activity; they give a predominantly inexpert chamber the intellectual resources to examine the government. This helps ensure that the public is informed about the way in which the country is run and, perhaps equally important, that the government is kept in touch with the values and opinions of ordinary people.

Though the legislature is well-placed to challenge the decisions of government it is not, generally, well-placed to make those decisions for itself. Mill criticises, perhaps to the point of parody, the treatment of detailed legislation within committees of the

${ }^{103}$ On the wide range of possible functions of a legislature see R. Packenham, "Legislatures and Political Development", reprinted in Norton, Legislatures.

104 J. Mill, "On Representative Government" in J. Mill, On Liberty and Other Essays, ed. J. Gray (Oxford 1991), at p. 282. 
Commons. ${ }^{105}$ Legislatures are poor drafters of legislation for two reasons. First, the bulk of representatives lack the technical knowledge required to properly formulate public policy. There will be many matters of which they are ignorant, and sometimes, perhaps frequently, the representatives will be ignorant of the scope of their ignorance. ${ }^{106}$ Secondly, the majority within the legislature is constantly shifting. There is little likelihood that the measures that a legislature would decide upon would be internally consistent, or even non-contradictory. A majority might be found for one clause of a bill, yet be lost when the second, counter-balancing, clause was being debated. In almost all Commonwealth countries it is the Government which draws up bills, and then places them before Parliament for approval. ${ }^{107}$

An obvious objection to the preceding discussion can be made; Congress has a crucial role in the drafting of legislation, and America does not seem to have significantly suffered from this. There are two answers to this challenge. First, Congress is an example of an institution that changed its form in order to accommodate the functions allotted to it. The rise in the role of committees within Congress enables the production of coherent laws. In the same way the British constitution entrusts the initial drafting of bills to the Cabinet, the American constitution places the power of legislative initiative in the hands of various congressional committees. Both of these devices narrow down the number of people involved in the bill's drafting, allowing the politicians with control of the process to develop expert skills and providing them with the support of professional policy advisors and legal draftsmen. ${ }^{108} \mathrm{~A}$ second development can also be perceived: perhaps in response to these difficulties the executive is taking an increasing role in the formulation of legislation. ${ }^{109}$ To an extent, Congress has lost its role as initiator and formulator of laws, and, like almost all other legislatures, has shifted towards being an institution of scrutiny, rather than initiative. Both these developments can only provide a partial solution; the involvement of the legislature in the drafting of statutes has significant implications for the nature of those statutes and for the balance of power between the courts and the legislature. The American method of statute creation leads to documents that are far less detailed and precise than their British counterparts, and, as a result,

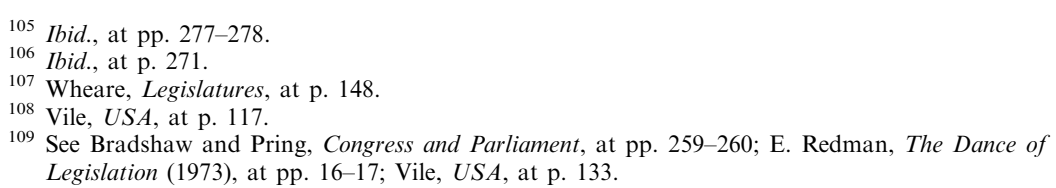


American judges are compelled to adopt a more purposive reading of statutes than is ordinarily the case in Britain. ${ }^{110}$

Despite the reservations expressed in the preceding paragraphs, there are some issues of public policy that legislatures can resolve effectively. Legislatures are at least as good as other institutions in reaching necessary decisions that do not admit of a technical solution. So, when a choice is being made between two incommensurable options, or where it is not possible to know the necessary facts on which a correct decision could be based, the legislature will be in no worse a position to reach a decision than the courts or the executive. It may make sense, depending on our understanding of the nature and importance of democracy, to leave such questions to the legislature, though it may often be a point of heated dispute whether or not an issue does fall into this category. This also demonstrates why it is not inappropriate to give legislatures a veto over executive action and legislation, though it may be inappropriate to allow the legislature to formulate such action itself. The legislature is enabled to reject the aim of the legislation or policy, but not the detailed methods that the drafters of the measure have adopted. This is a recognition of the legislature's ability to decide broad issues of policy, and a rejection of its ability to formulate detailed laws. ${ }^{11}$

\section{A Note on the Executive}

Having examined the forms of courts and legislatures and their consequent implications for the types of functions that should be accorded to these bodies, the apparent logic of separation of powers seems to dictate that there should now be a section on the executive, following the same model of analysis set out above. The diversity of executives between states and the variety of institutions within the executive render such an approach profitless. Though separation of powers has much to say about executive institutions there is little that can be usefully be said outside the bounds of an actual constitution. What our analysis of the institutions of the courts and legislature has shown is that other institutions, with technical expertise and investigative skills, are required for the proper functioning of the state. The precise form these take will depend on the local circumstances of the country, and the political theories that underpin its constitution.

${ }^{110}$ P.S. Atiyah, "Judicial Legislative Relations In England", at pp. 158-159, in R. Katzmann (ed.), Judges and Legislators: Towards Institutional Comity (Washington 1988).

111 J. Waldron, Law and Disagreement, at pp. 69-72. 


\section{Conclusion}

This article has explored the limits of separation of powers. Without the support of a political theory, and without consideration of the local environment in which the constitution operates, it can have no normative force. By adopting a thin normative stance it was possible to generate the sort of considerations that all understandings of the doctrine will produce; but the strength of this approach is also its weakness. Whilst these considerations apply in all constitutions in which separation of powers issues are raised, they are far from conclusive. It is only once a thicker, richer, political theory is introduced that substantive maxims for action can be generated. Given these variables it is unsurprising that there are many different doctrines of the separation of powers, both in the writing of academics and in the case law of particular states. We should be very slow to assume that any one interpretation is necessarily better than another. Sometimes, the balances struck are simply different, and there is little to be gained from trying to decide which is the best. The diversity of visions of separation of powers is to be welcomed; they reflect different local requirements and different, but perhaps equally justifiable, value judgments. This respectable diversity should make British judges slow to follow Barendt's injunction and embrace what is perceived as an American-style separation of powers model into the British legal system. The British courts already consider issues of institutional competency in defined areas; these may properly be termed "separation of powers" issues. There is, however, no obvious reason why the courts should assume a general jurisdiction to police divisions of power within the constitution. The power of the courts over other institutions is a crucial question of institutional competence: the court process is not necessarily the best forum for the crafting of our constitution. 